\title{
DAMPAK CERAI-GUGAT TKI/TKW TULUNGAGUNG PADA KESEHATAN MENTAL ANAK USIA DINI
}

\author{
Prajna Paramarthasatya Ningrum ${ }^{\mathrm{a}, 1}$, Anik Lestariningrum ${ }^{\mathrm{b}, 2}$ \\ a,b Universitas Nusantara PGRI Kediri, Indonesia \\ ${ }^{1}$ satyaningrum07@gmail.com, ${ }^{2}$ aniklestariningrum@gmail.com
}

\author{
Informasi artikel \\ Received: \\ Februari, 42022 \\ Revised : \\ Februari, 132022 \\ Publish :
}

Maret, 032022

Kata Kunci:

Cerai Gugat;

TKI/TKW;

Kesehatan

Mental;

Anak Usia Dini

\section{Keywords:}

Divorce;

TKI/TKW;

Mental health;

Early childhood

\begin{abstract}
ABSTRAK
Kesehatan mental adalah suatu pemikiran yang terdidik dari faktor keluarga dan lingkungan individu. Keadaan individu yang tidak terlepas dari berbagai bentuk turbulensi mental. Individu dapat dinyatakan memiliki kesehatan mental jika dapat menyesuaikan diri dan menyelesaikan masalah dengan pengelolaan stress yang baik. Pengaruh terbesar kesehatan mental adalah faktor keluarga. Karena, didalam keluarga individu merasa aman dan dicintai. Namun, terdapat perbedaan pada keluarga TKI/TKW. Keluarga TKI/TKW justru memiliki berbagai problematika dalam menjalankan hidup berkeluarga. Komunikasi yang kurang baik meningkatkan stress sehingga menimbulkan penurunan kesehatan mental. Kesehatan mental yang kurang baik memicu berbagai konflik dan berujung pada perpisahan (perceraian). Kabupaten Tulungagung di provinsi Jawa Timur, merupakan salah satu kabupaten dengan pengiriman TKI/TKW tertinggi, yaitu lebih dari 1000 tenaga kerja keluar negeri pertahun. Tetapi, kabupaten Tulungagung juga memiliki tingkat perceraian tertinggi yaitu 200-400 pengajuan cerai-gugat tiap bulan. Penelitian ini dilakukan untuk mengetahui faktor utama turunnya kesehatan mental keluarga TKI/TKW, serta motif perceraian yang telah dilakukan keluarga TKI/TKW serta mengetahui dampak yang dihasilkan dari perceraian. Metode penelitian yang digunakan adalah diskriptif kualitatif. Pengumpulan data menggunakan studi kepustakaan dan menggunakan pendekatan teori fenomenologi Alfred Schutz memuat motif sebab dan motif tujuan. Penurunan kesehatan mental bagi keluarga TKI/TKW karena beberapa faktor, yaitu: 1) perubahan gaya hidup, 2) adanya rasa kesepian dari dua belah pihak, 3) Kurangnya komunikasi, 4) tidak tersalurkannya harat sexsual, 5) hilangnya rasa tanggung jawab.
\end{abstract}

\section{ABSTRACT}

Mental health is an educated thought of the individual's family and environmental factors. Individual circumstances that can not be separated from various forms of mental turbulence. Individuals can be declared to have mental health if they can adjust and solve problems with good stress management. The biggest influence on mental health is the family factor. Because, in the family the individual feels safe and loved. However, there are differences in the families of Indonesian migrant workers. TKI/TKW families actually have various problems in carrying out family life. Poor communication increases stress, resulting in decreased mental health. Poor mental health triggers various conflicts and leads to separation (divorce). Tulungagung district in the province of East Java, is one of the districts with the highest number of migrant workers, which is more than 1000 workers abroad per year. However, Tulungagung district also has the highest divorce rate, which is 200-400 filings for divorce per month. This study was conducted to determine the main factors for the decline in the mental health of the families of Indonesian migrant workers, as well as the motives for divorce that have been carried out by the families of migrant workers and to determine the impact of divorce The research method used is descriptive qualitative. Collecting data using literature study and using Alfred Schutz's phenomenological theory approach containing cause and purpose motives. The decline in mental health for migrant workers' families is due to several factors, namely: 1) lifestyle changes, 2) a sense of loneliness from both parties, 3) lack of communication, 4) lack of sexual desire, 5) loss of responsibility.

This work is licensed under a Creative Commons Attribution-ShareAlike 4.0 International License. Allows readers to read, download, copy, distribute, print, search, or link to the full texts of its articles and allow readers to use them for any other lawful purpose. 


\section{PENDAHULUAN}

Tulungagung merupakan salah satu kabupaten di Jawa Timur yang turut menyumbangkan tingkat perceraian yang cukup tinggi. Tingkat perceraian dalam kurun waktu 2017 sampai tahun 2019 terus mengalami peningkatan.

Tabel 1. Peningkatan Perceraian

\begin{tabular}{|l|l|l|l|}
\hline Tahun & 2017 & 2018 & 2019 \\
\hline Angka Perceraian & 2910 & 2999 & 3037 \\
\hline
\end{tabular}

Pengadilan Agama Tulungagung juga mencatat bahwa terdapat 200-400 permohonan cerai setiap bulannya. Model cerai yang sering terjadi adalah cerai-gugat (70\%) dan cerai talak (30\%). Perceraian yang sering terjadi adalah berasal dari keluarga TKI (Muttaqin, 2019).

Dimana warga Tulungagung yang berasal dari pedesaan memilih bekerja di luar negeri karena merasa pekerjaan di desa tidak bisa mencukupi kebutuhan ekonomi keluarga. Namun, siapa sangka bahwa tren menjadi TKI/TKW menimbulkan problem meningkatnya perceraian. Para TKI/TKW mengajukan perceraian dengan berbagai alasan, seperti pihak ke tiga, ekonomi, gaya hidup, dan perubahan mindset. Karena berbagai problematika dalam berkeluarga maka kondisi metal individu juga akan menurun dan mengalami perubahan perlahan. Kurang terpenuhinya hasrat sexsual dan perhatian pasangan sehingga individu tertekan dan memilih untuk menjalin hubungan dengan pihak ke tiga. Karena kesehatan mental yang menurun akan memnyebabkan individu melupakan tugas dan kewajiban dalam berkeluarga.

Kesehatan mental merupakan unsur penting dalam kehidupan. Dengan mental yang sehat, maka aspek kehidupan individu yang lain akan berjalan secara maksimal. Begitu juga sebaliknya, individu yang memiliki mental yang kuat maka tidak akan memiliki gangguan motorik pada dan fisik. Secara motorik dan fisik merupakan salah satu bentuk pemahaman individu dalam penyesuaian diri terhadap lingkungan sekitarnya. Dalam persepsi person in environment menegaskan bahwa lingkungan dimana dia berada mempengaruhi individu itu sendiri. Lingkungan akan memberikan perubahan terhadap individu secara langsung maupun tidak langsung. Berdasar pernyataan tersebut, faktor lingkungan yang sangat mempengaruhi kesehatan mental adalah lingkungan keluarga. Keluarga dengan kesehatan mental yang baik akan dapat mencapai hubungan yang harmonis. Tetapi, keluarga yang tidak memiliki faktor 
pendidikan mental kurang baik akan sulit mencapai hubungan yang harmonis. Keluarga yang tidak harmonis dapat memicu permasalahan yang berujung perpisahan/perceraian.

Penelitian ini dilakukan untuk mengetahui: 1) faktor utama turunya kesehatan mental TKI/TKW, 2) motif perceraian yang telah dilakukan keluarga TKI/TKW, 3) mengetahui dampak yang ditimbulkan dari perceraian.

Kajian teori yang mendukung penelitian ini adalah kajian mengenai kesehatan jiwa/mental, psikologi perkawinan dan perceraian, serta dampak perceraian. UU Nomor 3 Tahun 1966 Bab I pasal 1 tentang Kesehatan Jiwa, kesehatan jiwa (mental health) menurut paham ilmu kedokteran pada waktu sekarang adalah satu kondisi yang memungkinkan perkembangan physik, intelektuil dan emosionil yang optimal dari seseorang dan perkembangan itu berjalan selaras dengan keadaan orang-orang lain. Makna kesehatan jiwa mempunyai sifat yang harmonis (serasi) dan memperhatikan semua segi dalam penghidupan manusia dan dalam hubungannya dengan manusia lain.

Keluarga TKI/TKW menjalin hubungan dengan cara hubungan jarak jauh, sehingga rasa saling ketergantungan sangatlah minim. Baron dan Byrne (2004: 5) mengangkat topik saling ketergantungan dalam hubungan. Saling ketergantungan merupakan dimana dua orang memiliki komitmen dalam mempengaruhi kehidupan satu sama lain, memusatkan emosi dan pikiran dengan teratur terlibat dalam aktivitas bersama. Serta memiliki hubungan akrap satu sama lain. Namun, semua berbeda dengan keluarga TKI/TKW, komitmen yang semakin lama memudar menyebabkan perasaan saling ketergantungan hilang, sehingga keberadaan pasangan yang jauh menjadi biasa saja bahkan banyak yang merubah komitmen dan merubah tujuan awal. Perubahan tersebut adalah suatu dasar munculnya konflik. Konflik merupakan suatu peristiwa yang menunjukkan pertentangan dan ketidak setujuan (lestari, 2012).

Keintiman memiliki peran penting dalam menjalin komunikasi dan mewujutkan hubungan yang romantis. Berdasar pendapat Erikson (dalam Valentini, \& Nisfiannoor, 2006) intimacy merupakan salah satu kemampuan komunikasi dan memiliki peran penting untuk meningkatkan keintiman dalam menjalin hubungan yang romantis. Pendapat Erikson didukung oleh pendapat Strong dan Devault (1989) yang menyatakan bahwa intimacy memiliki hubungan saling berkaitan dengan komunikasi, pasangan yang memiliki komunikasi kurang baik dapat dinyatakan tidak memiliki 
intimacy dalam hubungan mereka. Dan yang terjadi terhadap keluarga TKI/TKW adalah kurang adanya komunikasi, sehingga keluarga TKI/TKW dapat dinyatakan tidak memiliki intimacy dalam hubungan mereka. Kurangnya intimacy dalam hubungan menyebabkan hubungan rentan perpecahan dan konflik. Intimacy dapat berupa perasaan dalam suatu hubungan yang memiliki kedekatan antara dua orang yang ditandai dengan interaksi verbal maupun non verbal, keadaan mental, fisik serta sosial (Gustiah Rahmi, 2014).

\section{METODE}

Metode penelitian yang digunakan adalah Diskriptif Kualitatif, dengan alasan metode ini mampu mengungkap fenomena (gejala fenomenologis) yang ada dan disertai permasalahan yang eksplisit (terperinci). Metode ini digunakan dengan alasan dapat melakukan pendekatan dengan cara wajar, dan pengamatan bebas (tanpa pengaturan waktu ketat). Dan juga lebih dekat terhadap situasi dan kondisi yang ada pada sumber data (Subyantoro, 2007: 75-76). Literatur yang digunakan memiliki keterkaitan erat dengan penelitian yang dilakukan berasal dari buku, jurnal, maupun hasil penelitian lain yang dipublikasikan. Teknik pengumpulan data melalui studi kepustakaan, observasi, dan wawancara. Metode observasi merupakan suatu teknik untuk memperoleh data atau pengumpulan data dengan cara mengamati serta mencatat dengan terstruktur mengenai objek tertentu (Agung, 2012: 68). Didalam penelitian ini observasi digunakan untuk mengumpulkan data mengenai motif dan dampak perceraian TKI/TKW. Penelitian ini menggunakan pendekatan teori fenomenologi Alfred Schuttz yang memuat motif sebab dan motif tujuan. Motif sebab (because motive) adalah latar belakang yang mendorong individu melakukan tindakan, dan motif tujuan (in other to motive) adalah tujuan yang ingin dicapai individu berhubungan dengan tindakan yang dilakukan. Penelitian ini dilakukan di kabupaten Tulungagung, provinsi Jawa Timur.

\section{PEMBAHASAN}

\section{Faktor Turunnya Kesehatan Mental Pasangan TKI/TKW}

Kesehatan mental adalah kondisi dimana seorang individu dapat berkembang secara fisik, mental, spiritual,dan sosial sehingga individu tersebut menyadari 
kemampuan sendiri, dapat mengatasi tekanan, dapat bekerja secara produktif, dan mampu memberikan kontribusi untuk komunitasnya (UU pasal 1 nomor 18, 2014 tentang Kesehatan Jiwa). Terdapat dua faktor yang mempengaruhi kesehatan mental. Berikut tabel faktor internal dan eksternal yang mempengaruhi kesehatan mental TKI/TKW. Faktor di bawah ini juga mendorong adanya perceraian TKI/TKW.

Tabel 2. Faktor Pengaruh Kesehatan Mental TKI/TKW

\begin{tabular}{|c|c|}
\hline Fak & Faktor Eksternal \\
\hline $\begin{array}{l}\text { Kepribadian: } \\
\text { salah satu pihak atau kedua belah pihak } \\
\text { memiliki sifat yang tidak baik. } \\
\text { Seperti tidak setia, kurang paham mengenai } \\
\text { perasaan pasangan, tidak perduli terhadap } \\
\text { keluarga/anak. } \\
\text { Serta salah satu pasangan yang merasa } \\
\text { tertekan. } \\
\text { Keseimbangan dalam berfikir: } \\
\text { Karena adanya berbagai tekanan dalam } \\
\text { berkeluarga, menyebabkan berbagai bentuk } \\
\text { ketidak seimbangan dalam berfikir } \\
\text { (emosional) sehingga mudah marah, mencari } \\
\text { pelarian (mendorong munculnya pihak } \\
\text { ketiga), cara berfikir tidak jernih (tidak bijak } \\
\text { dalam menghadapi masalah dan mengambil } \\
\text { keputusan). } \\
\text { Kondisi psikologis: } \\
\text { Kurang adanya komunikasi yang baik dalam } \\
\text { hubungan, serta kurang terpenuhi nya hasrat } \\
\text { sexsual mendorong adanya berbagai bentuk } \\
\text { konflik. Konflik tersebut meliputi } \\
\text { munculnya pihak ketiga. } \\
\text { Stress yang berasal dari dalam diri seseorang } \\
\text { yang memicu perasaaan tidak nyaman, tidak } \\
\text { percaya dan mudah marah. } \\
\text { Stress yang berkepanjangan akan berujung } \\
\text { pada depresi sehingga seseorang lebih suka } \\
\text { menyendiri dan mengambil keputusan } \\
\text { sendiri tanpa mempertimbangkan apa yang } \\
\text { akan terjadi selanjutnya seperti keputusan } \\
\text { untuk bercerai. }\end{array}$ & $\begin{array}{l}\text { Ekonomi: } \\
\text { Faktor pendorong menjadi seorang TKI/TKW } \\
\text { adalah faktor ekonomi. } \\
\text { Masyarakat desa memiliki pendapat bahwa } \\
\text { pekerjaan di desa tidak dapat memenuhi } \\
\text { kebutuhan sehingga jalan satu-satunya untuk } \\
\text { bisa memenuhi kebutuhan dalam keluarga } \\
\text { adalah bekerja ke luar negeri. } \\
\text { Namun, siapa sangka bahwa setelah bekerja ke } \\
\text { luar negeri tetap muncul konflik karena } \\
\text { permasalahan ekonomi salah satunya adalah } \\
\text { tidak jujurnya TKI/TKW terhadap pasangan } \\
\text { yang di tinggalkan mengenai gaji dan penyalah } \\
\text { gunaan uang hasil kiriman. } \\
\text { Budaya dan lingkungan: } \\
\text { TKI/TKW: luar negeri memiliki budaya } \\
\text { dan lingkungan yang berbeda. Perbedaan } \\
\text { itu terlihat seperti cara berpakaian yang } \\
\text { terbuka, budaya bebas bergonta-ganti } \\
\text { pasangan. } \\
\text { Hal itu mendorong adanya perubahan } \\
\text { minsed (pola pikir) TKI/TKW. } \\
\text { Awal berangkat memiliki tujuan bekerja } \\
\text { namun setelah berada di luar negeri } \\
\text { mereka hanya bersenang-senang. } \\
\text { Pasangan yang ditinggalkan: } \\
\text { karena merasa bebas di rumah, adanya rasa } \\
\text { kesepian, dan tidak terpenuhinya hasrat } \\
\text { sexsual sehingga mendorong munculnya } \\
\text { perselingkuhan. } \\
\text { menyebabkan penyalahgunaan uang } \\
\text { kiriman, tidak menjalankan kewajiban, } \\
\text { serta hilangnya rasa setia. }\end{array}$ \\
\hline
\end{tabular}

Contoh konflik TKI karena kesehatan mental yang kurang baik sehingga keluarga TKI memilih menghancurkan rumahnya sendiri karena sang istri diketahui tidur dengan Kepala Desa. Keputusan rumah dirobohkan karena landasan emosi. Keputusan 
itu tidak memikirkan anak-anak mereka. Kedua belah pihak hanya memikirkan kebahagiaan pribadi sang istri yang memilih menikah lagi dan sang suami yang merasa rugi.

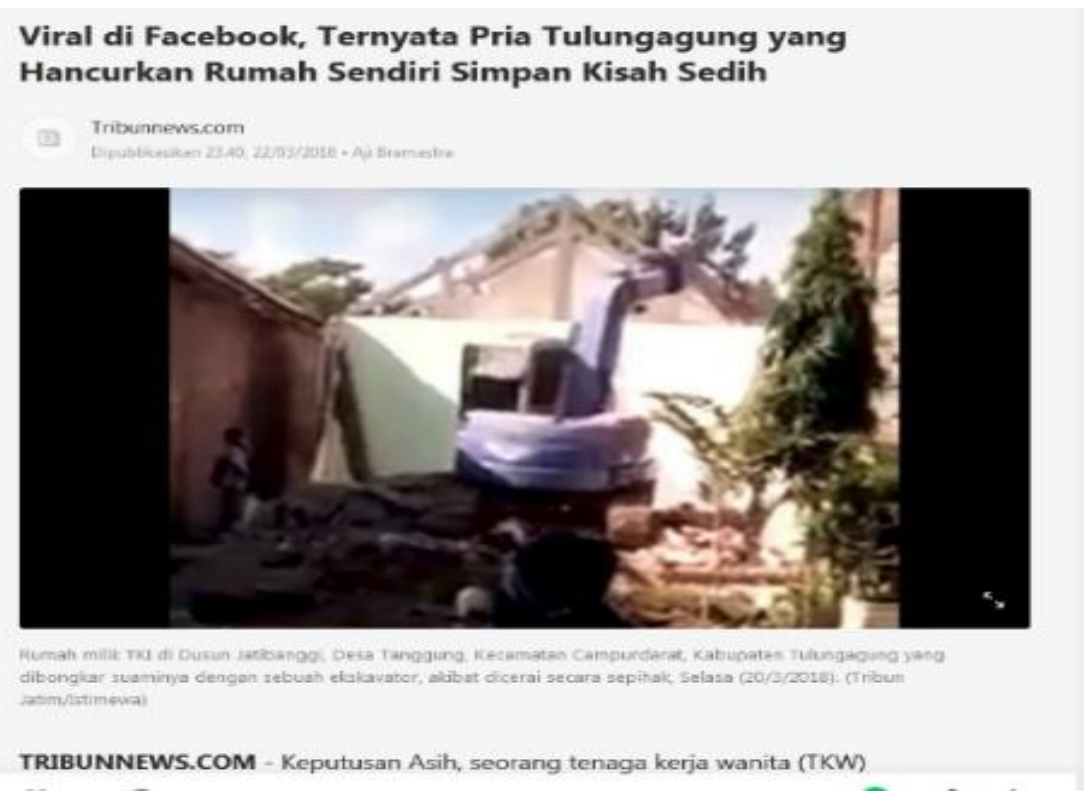

Gambar 1. Foto Rumah TKI yang Dihancurkan

Kejadian tersebut terjadi di Dusun Jatibanggi, Desa Tanggung, Kecamatan Campurdarat, Kabupaten Tulungagung, dibongkar menggunakan ekskavator, Selasa (20/3/2018). Hal itu terbukti salah satu pendorong perceraian adalah kesehatan mental yang kurang baik sehingga tidak dapat mengontrol emosi dan tidak dapat bijak dalam mengambil keputudan serta penyelesaian masalah.

\section{Motif Perceraian yang Telah Dilakukan Pasangan TKI/TKW}

Perceraian adalah berakhirnya hubungan yang sah sebagai suami-istri antara pria dan wanita. Namun berbeda hal-nya dengan keluarga TKI/TKW yang sebagian besar mengalami perpecahan karena berbagai permasalahan. Berikut berbagai bentuk permasalahan keluarga TKI/TKW kabupaten Tulungagung:

1) perubahan gaya hidup, 2) adanya rasa kesepian dari dua belah pihak, 3) Kurangnya komunikasi, 4) tidak tersalurkannya harat sexsual, 5) hilangnya rasa tanggung jawab, 6) kurang adanya rasa saling percaya. Dengan adanya berbagai problematika dalam menjalankan kehidupan berkeluarga, keluarga TKI/TKW sangatlah sensitif, sehingga sangat mudah mengalami disharmonisasi. Sehingga terjadi ketidakharmonisan dalam 
hidup berumah tangga. Jika suami dan istri dapat menyelesaikan permasalahan secara baik maka keluarganya akan berjalan harmonis. Namun, jika suami-istri tidak dapat menyelesaikan permasalahan dengan baik maka akan berujung pada perpecahan (perceraian).

Apabila dikaitkan dengan teori fenomenologi Alfred Schuttz terdapat dua konsep yang dapat di sebut in order to motive (motif tujuan) dan because to motive (motif sebab). Di dalam teori fenomenologi memiliki pandangan bahwa setiap tindakan yang dilakukan seseorang pasti memiliki tujuan yang ingin di capai sehingga oleh Alfred Schuttz disebut dengan in order to motive. Dan juga terdapat sebutan because to motive (motif sebab) yaitu segala tindakan seseorang memiliki sebab.

Tabel 3. Tipe Motif Sosial Menurut Alfred Schuttz

\begin{tabular}{|l|l|}
\hline \multicolumn{1}{|c|}{ Tipe Motif Sosial } & \multicolumn{1}{|c|}{$\begin{array}{c}\text { Motif Suami dan Istri Melakukan Perceraian } \\
\text { TKI/TKW }\end{array}$} \\
\hline $\begin{array}{l}\text { in order to motive } \\
\text { (motif tujuan) }\end{array}$ & $\begin{array}{l}\text { Ingin mengakhiri kesengsaraan hidup dan beban } \\
\text { penderitaan lahir batin. }\end{array}$ \\
\hline $\begin{array}{l}\text { because to motive } \\
\text { (motif sebab) }\end{array}$ & $\begin{array}{l}\text { Adanya ketidaksetiaan istri terhadap suami (pihak ke tiga). } \\
\text { Tidak terpenuhinya kebutuhan biologis, dan penyalah } \\
\text { gunaan uang kiriman, salah satu pihak yang diberikan } \\
\text { amanah mengurus anak yang ditinggalkan tidak } \\
\text { menjalankan tanggung jawab dengan baik, ketidak jujuran } \\
\text { atas hasil yang di dapat. }\end{array}$ \\
\hline
\end{tabular}

Berdasar tabel di atas, maka dapat di simpulkan bahwa perceraian terdapat dua motif yaitu motif tujuan dan motif sebab. Pijakan para keluarga TKI/TKW di Kabupaten Tulungagung pada dasarnya karena adanya tujuan yang melatar belakanginya, dan sebab yang menjadi pijakan para keluarga TKI/TKW untuk melakukan perceraian.

\section{Dampak yang Ditimbulkan dari Perceraian TKI/TKW Pada Anak Usia Dini}

Perlu kita ketahui bahwa perceraian memiliki dampak yang cukup besar terhadap kehidupan selanjutnya, dampak perceraian tersebut lebih dominan terhadap wanita daripada pria. Untuk patah hati pasti dirasakan oleh kedua belah pihak, namun terdapat alasan lain mengapa wanita lebih terpukul daripada pria. Wanita mengalami guncangan berat akibat perceraian karena rasa khawatir terhadap masalah ekonomi 


\section{(financial) terutama wanita yang sudah memiliki anak. Berikut tabel yang berisi}

dampak perceraian:

\section{Tabel 4. Dampak Perceraian Terhadap Berbagai Pihak}

\begin{tabular}{|c|c|}
\hline Bagi Wanita & $\begin{array}{l}\text { Wanita memiliki tekanan yang berat karena kekhawatiran yang tinggi akan } \\
\text { masalah financial. Khususnya para wanita yang memutuskan berhenti bekerja } \\
\text { karena menikah dan mengurus anak. Namun karena adanya perceraian wanita yang } \\
\text { sudah mencapai usia paruh waktu harus mencari pekerjaan dan menghidupi anak } \\
\text { dengan gaji yang seadanya. Terdapat dampak lainnya yang dirasakan wanita } \\
\text { selama proses dan setelah proses prceraian adalah: } \\
\checkmark \quad \text { Stres: wanita memiliki tekanan psikologis lebih tinggi dan signifikan daripada } \\
\text { pria. Tekanan ini menimbulkan ketidak percayaan wanita terhadap pria. Bisa } \\
\text { juga karena adanya perceraian wanita menganggap bahwa semua pria sama. } \\
\text { Cemas: setelah mengalami perceraian wanita memiliki rasa khawatir yang } \\
\text { sangat tinggi. Rasa khawatir tersebut meliputi rasa khawatir terhadap masa } \\
\text { depan yang tidak pasti dan terlihat suram. } \\
\text { Takut: rasa khawatir yang berlebih maka tidak menutup kemungkinan wanita } \\
\text { memiliki rasa takut. Ketakutan tersebut meliputi takut menjalin hubungan } \\
\text { baru, takut berkomitmen dan jatuh cinta lagi. } \\
\text { Marah: karena adanya tekanan akibat perceraian maka kesehatan psikologis } \\
\text { wanita terganggu. Dampak yang buruk akibat marah adalah munculnya } \\
\text { keinginan menyakiti mantan suami atau bahkan pelampiasan amarah kepada } \\
\text { anak. Bisa juga wanita yang bercerai balas dendam dengan berkencan bersama } \\
\text { pria yang sudah menikah. } \\
\text { Perempuan yang bercerai dihantui rasa bersalah, rasa bebas, tetapi wanita juga } \\
\text { akan lebih merasa bertanggung jawab. Maka dari itu tak jarang wanita yang } \\
\text { sudah bercerai memiliki perubahan drastis berupa fisik maupun karir. }\end{array}$ \\
\hline $\mathrm{Baq}$ & $\begin{array}{l}\text { Kondisi pria setelah bercerai sangatlah sedih dan patah hati. Pria cenderung } \\
\text { mengalihkan perhatiannya seperti menjalin hubungan baru dengan wanita lain, cuti } \\
\text { kerja untuk liburan, atau bahkan melakukan seks bebas. pria cenderung memilih } \\
\text { untuk mengobati luka daripada melupakan luka dengan berbagai cara positif } \\
\text { seperti memperbanyak waktu berkumpul bersama teman. Pria memiliki perasaan } \\
\text { bersalah atas terjadinya perceraian lebih tinggi daripada wanita. }\end{array}$ \\
\hline $\mathrm{Bag}$ & $\begin{array}{l}\text { Perceraian orangtua juga memiliki dampak yang besar terhadap anak. Dampak } \\
\text { perceraian terhadap anak meliputi: } \\
\checkmark \quad \text { Stress, cemas dan takut. Perasaan tersebut akan muncul kepada anak, terlebih } \\
\text { jika anak sudah mampu untuk mengamati situasi. Anak akan merasa } \\
\text { terabaikan dan merasa tidak dicintai. Anak yang terbiasa hidup dengan ayah } \\
\text { dan ibu secara tiba-tiba hanya tinggal bersama salah satu dari orangtua mereka. } \\
\text { Rasa aman dengan orang tua yang lengkap setelah adanya perceraian rasa } \\
\text { aman sudah tidak ada lagi. } \\
\checkmark \text { Anak akan merasa rendah diri karena tidak memiliki keluarga yang lengkap } \\
\text { seperti teman sebayanya. Anak juga bisa mengalami penurunan prestasi } \\
\text { belajar karena tidak adanya dukungan orangtua. } \\
\checkmark \text { Dalam jangka panjang anak juga mengalami trauma untuk memulai hubungan } \\
\text { terhadap lawan jenisnya dan merasa takut untuk berkomitmen. } \\
\text { Anak mudah masuk kedalam pergaulan bebas karena kurang adanya } \\
\text { pengawasan orangtua atau anak broken home. } \\
\checkmark \text { Anak juga berpotensi melakukan seks bebas. Rasa kurang kasih sayang yang } \\
\text { diberikan orangtua memiliki potensi tinggi terhadap anak untuk mencari kasih } \\
\text { sayang di luar rumah. } \\
\text { Anak juga berpotensi menyalahkan diri sendiri. Anak merasa tidak bisa } \\
\text { membanggakan orangtua, dan sebagai pemicu pertengkaran orang tua. }\end{array}$ \\
\hline
\end{tabular}




\section{SIMPULAN}

Permasalahan ekonomi merupakan salah satu faktor pendukung seseorang memutuskan untuk bekerja di luar negeri. Masyarakat di Tulungagung berpendapat bahwa bekerja di desa tidak dapat memenuhi kebutuhan sehingga masyarakat desa memilih menjadi TKI/TKW. Namun pada kenyataannya hidup tidak semudah memutar balikkan telapak tangan. Setelah menjadi TKI/TKW justru muncul berbagai masalah baru seperti perselingkuhan, tidak adanya tanggung jawab, dan ketidakjujuran dalam berkeluarga. Dengan berbagai masalah keluarga yang ada maka tidak menutup kemungkinan turunnya kesehatan mental dalam berkeluarga. Penurunan kesehatan mental bagi keluarga TKI/TKW karena beberapa faktor, yaitu: 1) perubahan gaya hidup, 2) adanya rasa kesepian dari dua belah pihak, 3) Kurangnya komunikasi, 4) tidak tersalurkannya hasrat sexsual, 5) hilangnya rasa tanggung jawab. Dengan menurunnya kesehatan mental maka keluarga tidak dapat menyelesaikan masalah dengan baik sehingga keluarga TKI/TKW banyak yang memutuskan untuk bercerai. Perceraian tersebut didorong adanya motif sebab dan motif tujuan. Perceraian juga memiliki dampak yang besar pada kehidupan selanjutnya. Dampak perceraian berdampak terhadap wanita, pria dan bahkan anak.

Perceraian bukanlah hal yang baik didalam keluarga. Sangat dianjurkan untuk keluarga TKI/TKW bisa menjalin hubungan yang baik dengan keluarga. Menjalankan amanah dengan baik, adanya perasaan terbuka terhadap pasangan, tetap menjalin komunikasi yang baik dengan keluarga, serta setia dan tetap menjaga komitmen. Karena perceraian memiliki dampak yang sangat merugikan bagi keluarga itu sendiri.

\section{UCAPAN TERIMA KASIH}

Melalui publikasi di jurnal ilmiah ini kami menyampaikan ucapan terima kasih kepada seluruh pihak yang telah membantu terselesaikannya penulisan artikel ini tepat waktu. Terima kasih kepada seluruh narasumber informasi yang mau diwawancarai, co-author sekaligus dosen pembimbing artikel yang tidak hanya mendampingi proses pembuatan tetapi berperan serta menulis dan kepada seluruh Dosen PG-PAUD Universitas Nusantara PGRI Kediri atas bekal pengetahuan pemahaman subtansi anak usia dini yang diterima saat perkuliahan membantu pemahaman menulis artikel ini 


\section{REFERENSI}

Agung, Iskandar . 2012. Panduan Penelitian Tindakan Kelas bagi Guru. Jakarta: Bestari Buana Murni.

Baron, Roberta A. dan Donn Byrne. 2004. Perilaku Organisasi, Ratna Djuwita, Jakarta: Erlangga.

Gustiah, R. 2014. Hubungan Antara Intimacy Dengan Kepuasan Pernikahan Pada Silver Age.

Lestari, S. 2012. Psikologi keluarga: Penanaman Nilai dan Penanganan Konflik Dalam Keluarga. Jakarta: Kencana Prenada Media Group.

Muttaqin. 2019. Perceraian di Tulungagung Meningkat, Setahun Ada 2.611 Janda Baru. Available at: https://news.detik.com (Accessed: 2 Juni 2021).

Strong, Bryan \& Christine DeVault. 1989. The Marriage and Family Experience 4thed. California : West Pub. Co.,

Subyantoro, Arief dan Suwarto, FX. 2007. Metode dan Teknik Penelitian Sosial. Yogyakarta: Andi.

Tribunnews.com, 2018. Viral di Facebook, Ternyata Pria Tulungagung yang Hancurkan Rumah Sendiri Simpan Kisah Sedih. Available at: https://today.line.me/id/v2/article/o8Oom5 (Accessed: 5 Juni 2021)

Undang-Undang nomor 18 Tahun 2014 pasal 1 tentang Kesehatan Jiwa

Undang-Undang Nomor 3 Tahun 1966 bab I pasal 1 tentang Kesehatan Jiwa

Undang-Undang Republik Indonesia Nomor 3 Tahun 1966 tentang Kesehatan Jiwa Bab I Pasal 1

Valentini, Veronica, Nisfiannoor, M. Jurnal Provitae Vo.2 No.1 Mei 2006. Identity Achievement Dengan Intimacy Pada Remaja SMA. Jakarta: Buku Obor Fakultas Psikologi Universitas Tarumanagara Jakarta Bekerjasama dengan Yayasan Obor Indonesia.

Wijaya, Yeni Duriana. 2019. Kesehatan Mental di Indonesia : Kini dan Nanti. Buletin Jagaddhita Vol. 1, No. 1, Februari 2019. Available at: https://jagaddhita.org/kesehatan-mental-di-indonesia-kini-dan-nanti/ (Accessed: 3 Juni 2021). 